\title{
Lung Inflammatory Responses to Intratracheal Interleukin-1 $\alpha$ in Ventilated Preterm Lambs
}

\author{
NEIL MULROONEY, ALAN H. JOBE, AND MACHIKO IKEGAMI \\ Neonatology/Pulmonary Biology [N.M., A.H.J., M.I.], Cincinnati Children's Hospital Medical Center, \\ Cincinnati, Ohio 45229, U.S.A.
}

\begin{abstract}
Interleukin- $1 \alpha$ is an early response proinflammatory cytokine that has been associated with chorioamnionitis and preterm labor, brain injury, and bronchopulmonary dysplasia. However, IL- $1 \alpha$ also can increase expression of surfactant proteins and induce lung maturation in the preterm fetus. We measured the effects of IL- $1 \alpha$ given by intratracheal instillation (IT) and compared the responses with injection of i.v. IL- $1 \alpha$ in surfactant-treated and ventilated premature lambs. IT recombinant ovine IL- $1 \alpha$ at doses of 5 and $50 \mu \mathrm{g} / \mathrm{kg}$ caused a similar large recruitment of neutrophils into the bronchoalveolar lavage fluid. The neutrophils expressed CD11b, CD14, and CD44, but did not produce increased amounts of $\mathrm{H}_{2} \mathrm{O}_{2}$. Cells from the bronchoalveolar lavage fluid had increased expression of proinflammatory cytokines, which also were increased in mRNA from lung tissue. The IT IL- $1 \alpha$ also suppressed the expression of surfactant protein-C mRNA. Systemic effects were decreased neutrophils in blood, decreased lung function, increased heart rate, and hypotension or
\end{abstract}

\section{ABSTRACT}

death in the $50 \mu \mathrm{g} / \mathrm{kg}$ IL- $1 \alpha$ IT group and only decreased neutrophils in the blood in the $5 \mu \mathrm{g} / \mathrm{kg}$ IL- $1 \alpha$ IT group. The i.v. IL- $1 \alpha$ caused no lung inflammation or injury but did result in severe neutropenia and hypotension leading to early death. IT IL-1 $\alpha$ can cause intense lung inflammation and systemic shock in ventilated preterm lungs. (Pediatr Res 55: 682-687, 2004)
IT, intratracheal instillation
Abbreviations
TNF, tumor necrosis factor
PIP, peak inspiratory pressure
PEEP, positive end-expiratory pressure
VEI, ventilatory efficiency index
$\mathrm{Fio}_{2}$, fraction of inspired oxygen
$\mathrm{V}_{\mathrm{T}}$, tidal volume
SP-A, -B, -C, -D, surfactant protein A, B, C, or D
BALF, bronchoalveolar lavage fluid

Preterm infants are frequently exposed to chorioamnionitis before delivery and inflammation after delivery as a consequence of the inflammatory effects of supplemental oxygen, mechanical ventilation, and nosocomial infection (1). These inflammatory exposures contribute to bronchopulmonary dysplasia and poor neurodevelopmental outcomes $(2,3)$. IL-1 is of particular interest in perinatal medicine because it is present in chorioamnionitis and associated with preterm delivery, is induced in the lungs by mechanical ventilation, and is persistently in airway samples from infants developing bronchopulmonary dysplasia (4-6). IL-1 is induced by endotoxin, and endotoxin and IL-1 have similar physiologic effects and share a common intracellular signaling pathway (7). IL- $1 \alpha$ or IL-1 $\beta$ also induce lung inflammation and lung maturation when given by intraamniotic injection in rabbits and sheep, indicating that

Received June 6, 2003; accepted November 14, 2003.

Correspondence: Machiko Ikegami, M.D., Ph.D., Cincinnati Children's Hospital, Division of Pulmonary Biology, 3333 Burnet Avenue, Cincinnati, OH 45229-3039, U.S.A.; e-mail: machiko.Ikegami@cchmc.org

Supported by grant HD-12714 from the National Institute of Child Health and Development.

DOI: 10.1203/01.PDR.0000112104.48903.3C
IL-1 can have beneficial as well as harmful effects (8-10). IL- $1 \alpha$ and IL- $1 \beta$ are early response inflammatory cytokines that modulate their own production and induce other proinflammatory cytokines including IL-6, IL-8, and TNF- $\alpha$ (1113). IL- $1 \alpha$ is cell surface associated and IL- $1 \beta$ is a soluble cytokine, and both share the same receptors and have similar biologic activity (14).

The interpretation of the effects of a proinflammatory mediator is complicated by the number of mediators, the ability of a mediator to induce other mediators in the proinflammatory cascade, and possible differences in responses caused by an immature innate immune system in the preterm. In the adult rat and hamster, intratracheal IL- $1 \alpha$ recruits neutrophils to the lungs and causes pulmonary edema without remarkable systemic effects $(15,16)$. These responses to intratracheal IL- 1 are similar to intratracheal TNF- $\alpha$ or endotoxin in the adult animal $(17,18)$. We recently reported that ventilated preterm lambs given intratracheal endotoxin developed lung inflammation and systemic effects because the endotoxin leaked from the lungs into the systemic circulation (19). In contrast, intratracheal TNF- $\alpha$ induced only a modest inflammatory response in preterm lamb lungs and no systemic effects (20). Therefore, we 
evaluated the responses of preterm ventilated lambs to intratracheal IL- $1 \alpha$ with the hypothesis that IL- $1 \alpha$ would replicate the lung injury and systemic effects of endotoxin.

\section{METHODS}

Delivery, cytokine exposure, and ventilation. We evaluated lung effects and systemic responses of IT and i.v. ovine recombinant IL- $1 \alpha$ on the lungs as well as systemic responses in preterm lambs. The protocol was approved by the Animal Care and Use Committee of the Cincinnati Children's Hospital Research Foundation. Preterm lambs were delivered by cesarean section at 129-130 d gestational age from Suffolk ewes bred to Dorset rams (term gestation is $150 \mathrm{~d}$ ). On exposure of the fetal neck and head, an endotracheal tube was tied into the trachea. Fetal lung fluid was aspirated before delivery of the lambs. The lambs were delivered, weighed, and randomized to receive $100 \mathrm{mg} / \mathrm{kg}$ surfactant (Survanta, Ross Products, Columbus, OH, U.S.A.) that had been mixed with $5 \mu \mathrm{g} / \mathrm{kg} \mathrm{IL}-1 \alpha$, $50 \mu \mathrm{g} / \mathrm{kg}$ IL- $1 \alpha$, or saline. We used sheep recombinant IL- $1 \alpha$ that was custom synthesized by Protein Express (Cincinnati, OH, U.S.A.). The IL- $1 \alpha$ did not contain endotoxin when tested with the Limulus lysate assay (Bio Whittaker/Cambrex, Walkersville, MD, U.S.A.). We used the same preparation that was previously shown to induce chorioamnionitis, lung inflammation, and fetal lung maturation after intraamniotic injection (10, 20). Other animals were delivered, treated with surfactant, and given $15 \mu \mathrm{g} / \mathrm{kg}$ i.v. of IL- $1 \alpha$ at $5 \mathrm{~min}$ of age to evaluate the systemic effects of IL- $1 \alpha$. In preliminary experiments $20-25$ $\mu \mathrm{g} / \mathrm{kg} \mathrm{IL}-1 \alpha$ given by i.v. injection caused shock, and 2-2.5 $\mu \mathrm{g} / \mathrm{kg} \mathrm{IL}-1 \alpha$ had minimal pulmonary or systemic effects. A $5 \mathrm{~F}$ umbilical artery catheter was placed in the aorta immediately after delivery, and $10 \mathrm{~mL} / \mathrm{kg}$ filtered placental blood was given to the animals.

The animals were ventilated with time-cycled and pressurelimited infant ventilators (Sechrist Industries, Anaheim, CA, U.S.A.) with initial settings of: a rate of 40 breaths/min; an $\mathrm{Fio}_{2}$ of 1.0; an inspiratory time of $0.6 \mathrm{~s}$; a PEEP of $4 \mathrm{cmH}_{2} \mathrm{O}$; and a PIP limited to provide less than $10 \mathrm{~mL} / \mathrm{kg} \mathrm{V}_{\text {T }}$ without exceeding $35 \mathrm{~cm} \mathrm{H}_{2} \mathrm{O}$. Peak pressure and $\mathrm{Fio}_{2}$ adjustments were made to keep the $\mathrm{PCO}_{2}$ between 45 and $55 \mathrm{~mm} \mathrm{Hg}$ and the $\mathrm{PO}_{2}$ between 150 and $200 \mathrm{~mm} \mathrm{Hg}$ whenever possible. The ventilation strategy to use PEEP, a maximal PIP of $<35 \mathrm{~cm}$ $\mathrm{H}_{2} \mathrm{O}$, and $\mathrm{V}_{\mathrm{T}}$ of $<10 \mathrm{~mL} / \mathrm{kg}$ in surfactant-treated preterm lambs was designed to limit ventilator-induced lung injury (21, 22). VT of $7-9 \mathrm{~mL} / \mathrm{kg}$ are required to control $\mathrm{PCO}_{2}$ in preterm lambs ventilated with a rate of 40 breaths $/ \mathrm{min}$. VT was monitored continuously using Bicore CP-100 neonatal pulmonary monitors (Bicore Monitoring Systems, Irvine, CA, U.S.A.). Dynamic compliances were calculated using intermittent VT measurements made with a pneumotachometer, normalized to body weight, and divided by the ventilatory pressure (PIP PEEP) (23). The VEI was calculated as VEI $=3,800 /$ [respiratory rate $\left.\times(\mathrm{PIP}-\mathrm{PEEP}) \times \mathrm{PCO}_{2}\right]$ (24).

The umbilical artery catheter was used for blood gases as well as heart rate and blood pressure recordings. A peripheral i.v. catheter was used to infuse $10 \%$ dextrose $(100 \mathrm{~mL} / \mathrm{kg}$ per day). Rectal temperature was continuously monitored and maintained at $38^{\circ}-39^{\circ} \mathrm{C}$ with heating pads and radiant warmers. Supplemental ketamine (10 $\mathrm{mg} / \mathrm{kg}$ intramuscularly) and acepromazine $(0.1 \mathrm{mg} / \mathrm{kg}$ intramuscularly) were used to suppress spontaneous respirations. Blood was collected at 0, 2, 4, and $6 \mathrm{~h}$ for white blood cell counts. After $6 \mathrm{~h}$ the animals were deeply anesthetized with pentobarbital given i.v. and ventilated briefly with $100 \%$ oxygen. The endotracheal tube was clamped for 2 min to permit lung collapse by oxygen absorption.

Lung gas volume and lung processing. The thorax was opened, and lungs were inflated with air to $40 \mathrm{~cm} \mathrm{H}_{2} \mathrm{O}$ pressure for $1 \mathrm{~min}$ to measure the maximal lung volume (21). The pressure was then decreased to measure the lung volume at 20 , $15,10,5$, and $0 \mathrm{~cm} \mathrm{H}_{2} \mathrm{O}$ pressure. Lung tissue from the right lower lobe was frozen in liquid nitrogen for RNA isolation. Bronchoalveolar lavage was repeated five times by filling the left lung with $0.9 \%$ saline solution at $4^{\circ} \mathrm{C}$, and the BALF samples were pooled. Aliquots of BALF were saved for measurement of total protein, cell number, and cell differential counts. Cell pellets were used for hydrogen peroxide assay and RNA isolation. Total protein in BALF was measured using the Lowry assay (25).

Alveolar cells. An aliquot of each BALF was centrifuged at $500 \times g$ for $10 \mathrm{~min}$. The number of cells was counted using trypan blue to identify viable cells. Differential cell counts were performed on cytospin preparations stained with DiffQuick (Scientific Products, McGaw Park, IL, U.S.A.). Activation of the cells recruited to the airways was assessed by measuring hydrogen peroxide using an assay based on the oxidation of ferrous iron $\left(\mathrm{Fe}^{2+}\right)$ to ferric iron $\left(\mathrm{Fe}^{3+}\right)$ by hydrogen peroxide under acidic conditions (Bioxytech $\mathrm{H}_{2} \mathrm{O}_{2}-$ 560 assay, OXIS International, Portland, OR, U.S.A.) (26). Aliquots of BALF cells were incubated on ice with MAb against bovine CD11b ( $\alpha$ M-subunit of integrin CR3), ovine CD14 (endotoxin activation receptor), and porcine CD44 (proteoglycan link protein). The cell pellet was washed twice with PBS to remove unbound antibody and incubated with phycoerythrin-labeled $F\left(a b^{\prime}\right) 2$ anti-IgG fragments (secondary antibody) in the dark on ice. Cells were subsequently washed twice and resuspended in PBS, kept on ice, and immediately analyzed on FACS Caliber flow cytometer (Becton Dickinson, Mountain View, CA, U.S.A.).

Cytokine mRNA. Total RNA was isolated from tissue from the right lower lobe and BALF cells using guanidinium thiocyanate-phenol-chloroform extraction (27). RNase protection assays were performed using transcripts of ovine IL- $1 \beta$, IL-6, IL-8, IL-10, and IL- $1 \alpha$ as previously described $(20,28)$. The mRNA for the ovine ribosomal protein L32 was the reference RNA. Densities of the protected bands were quantified on a phosphor imager using ImageQuant software (Molecular Dynamics Inc., Sunnyvale, CA, U.S.A.).

Surfactant protein $\boldsymbol{m R N A}$. The mRNA for surfactant proteins SP-A, SP-B, SP-C, and SP-D were measured using S1 nuclease protection assays as previously described (29). Briefly, an excess of linearized probes for the ovine surfactant proteins and L32 that were end labeled with $\left[{ }^{32} \mathrm{P}\right] \mathrm{ATP}$ were hybridized at $55^{\circ} \mathrm{C}$ with $3 \mu \mathrm{g}$ of total RNA from lung tissue. After incubation with $\mathrm{S} 1$ nuclease, the protected fragments 
were resolved on $6 \%$ polyacrylamide $-8 \mathrm{~mol}$ urea sequencing gels, visualized by autoradiography, and quantified.

Data analysis. Results are given as mean \pm SEM. Significance was tested by four-group ANOVA using parametric (Tukey) or nonparametric (Dunn) tests as appropriate using Instat 2.03 GraphPad Software (San Diego, CA, U.S.A.). Selectively, groups were compared by $t$ test versus control. Significance was accepted at $p<0.05$.

\section{RESULTS}

Lung function. There were no significant differences in the mean body weights of the lambs in each group (Table 1). The animals in all groups were alive and stable after $4 \mathrm{~h}$ of ventilation. After $4 \mathrm{~h}$, three of seven IT $50 \mu \mathrm{g} / \mathrm{kg} \mathrm{IL}-1 \alpha$-treated lambs died early secondary to severe shock and another animal in this group was severely hypotensive at $6 \mathrm{~h}$. In the i.v. IL- $1 \alpha$ group, two animals developed severe hypotension and died early. Severe hypotension was defined as a mean arterial pressure of less than $15 \mathrm{~mm} \mathrm{Hg}$. Thus, the respiratory variables between groups are compared at $4 \mathrm{~h}$, before the early losses. The animals given $50 \mu \mathrm{g} / \mathrm{kg}$ IL- $1 \alpha$ IT required significantly higher mechanical ventilator settings (PIP - PEEP) than all other animals. Despite the higher ventilation pressure settings, these animals were more acidotic. This group also had lower $\mathrm{PO}_{2} / \mathrm{FiO}_{2}$ when compared by $t$ tests with control lambs. VEI, which measures gas exchange, also decreased by $2 \mathrm{~h}$ in the 50 $\mu \mathrm{g} / \mathrm{kg} \mathrm{IL}-1 \alpha$ IT group (Fig. 1). Lung volumes measured with pressure-volume curves also decreased in this high-dose group. The $5 \mu \mathrm{g} / \mathrm{kg} \mathrm{IL-} 1 \alpha$ IT and $15 \mu \mathrm{g} / \mathrm{kg} \mathrm{IL-} 1 \alpha$ i.v. groups had no significant differences in lung function during the 6-h study period.

Cellular indicators of lung inflammation. Cells in BALF increased by 10 fold in the $5 \mu \mathrm{g} / \mathrm{kg} \mathrm{IL}-1 \alpha$ IT group and by 13 fold in the $50 \mu \mathrm{g} / \mathrm{kg}$ IL- $1 \alpha$ IT group relative to the Controls (Fig. 2). The majority of cells were neutrophils that increased in the BALF by about 40 fold in both the IT IL- $1 \alpha$ groups. $\mathrm{H}_{2} \mathrm{O}_{2}$ production by the cells from the BALF was not different from the controls when expressed per kg body weight of the animals. However, hydrogen peroxide production when expressed per million cells in the BALF decreased by greater than 10 fold in the animals that received IT IL- $1 \alpha$. FACS analysis demonstrated increased expression of CD11b, CD14, and
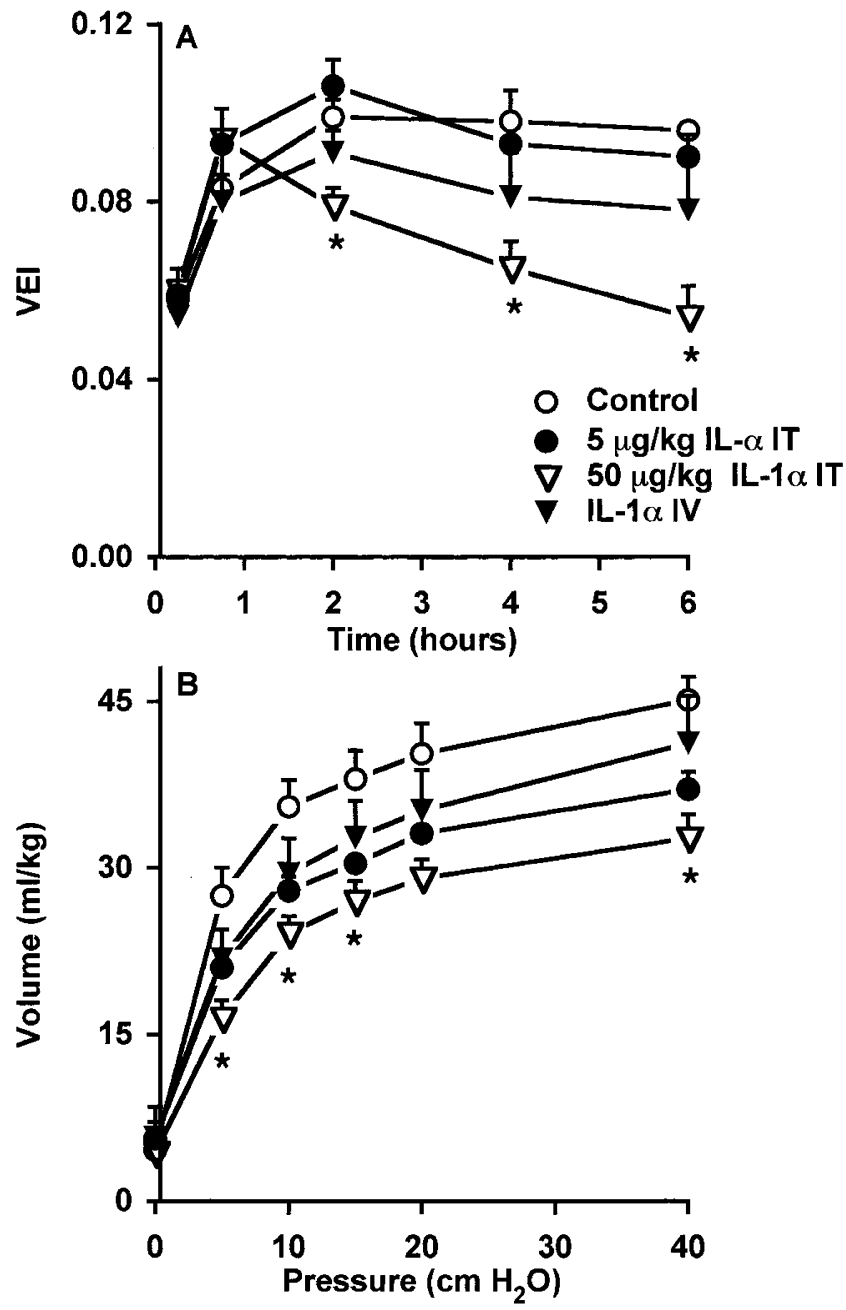

Figure 1. $A$, VEI decreased significantly with time after delivery only for the lambs given $50 \mu \mathrm{g} / \mathrm{kg} \mathrm{IL}-1 \alpha$ by IT. ${ }^{*} p<0.05 v s$ other groups. The number of animals per study group are 6 controls and 7 in the other groups through $4 \mathrm{~h}$. After $4 \mathrm{~h}$, the IT 50 group had 5 animals. $B$, lung volumes measured on deflation limbs of pressure-volume curves for the $50 \mu \mathrm{g} / \mathrm{kg}$ IL- $1 \alpha$ IT group were lower than for the other groups by ANOVA, ${ }^{*} p<0.05 . n=6$ for controls and 7 for the other groups.

CD44 in both groups of animals exposed to intratracheal IL- $1 \alpha$. The IL-1 $\alpha$ i.v. group did not demonstrate a change in BALF cells, $\mathrm{H}_{2} \mathrm{O}_{2}$ production or antigen expression relative to

Table 1. Description of lambs and pulmonary function after $4 \mathrm{~h}$ of mechanical ventilation

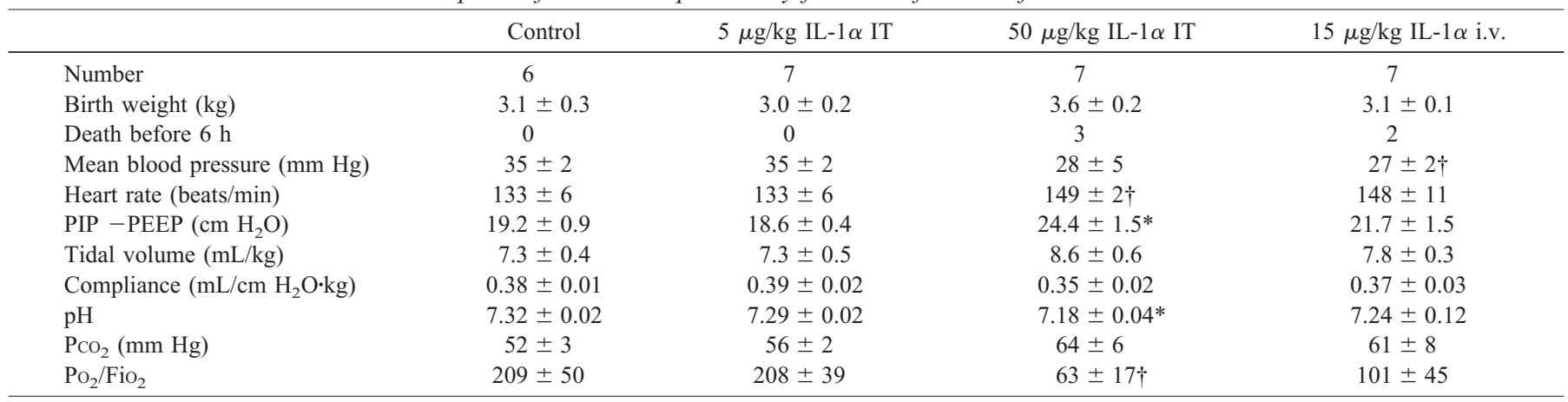

These values are reported at $4 \mathrm{~h}$ because of the high number of early deaths.

$* p<0.05$ by ANOVA, $\dagger p<0.05$ by $t$ test $v s$ control lambs. 

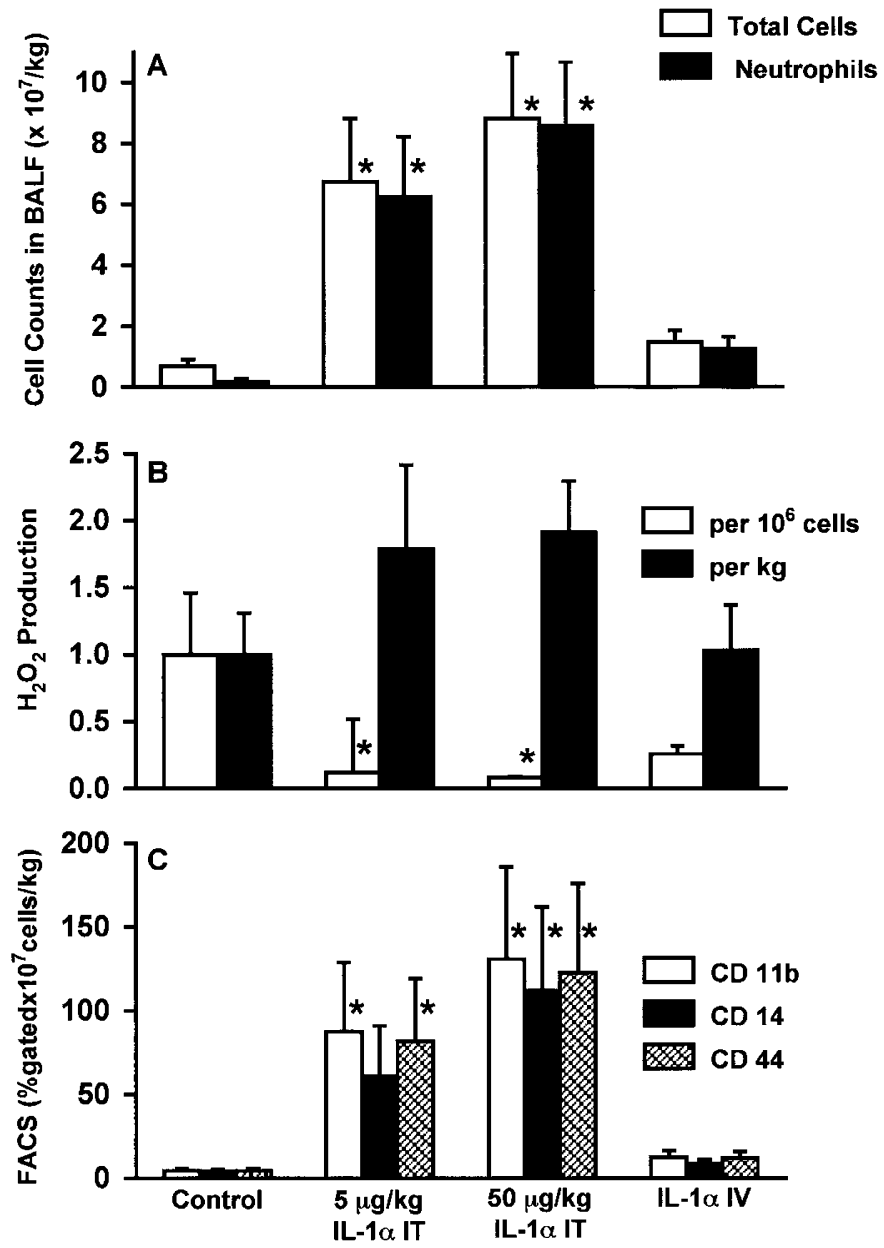

Figure 2. $A$, total cells and neutrophils increased for the groups that received IT IL- $1 \alpha$ but not i.v. IL- $1 \alpha$. $B, \mathrm{H}_{2} \mathrm{O}_{2}$ production expressed as micromoles for cells per kilogram of body weight (solid bars) was not different among groups. However, when expressed per $10^{6}$ cells in BALF (white bars), the amount of $\mathrm{H}_{2} \mathrm{O}_{2}$ decreased for the groups given IT IL- $1 \alpha$. The values are normalized to the values for the control group, which were $236 \mu \mathrm{mol} \mathrm{H}_{2} \mathrm{O}_{2} / \mathrm{kg}$ and 73 $\mu \mathrm{mol} / 10^{6}$ cells in BALF. $C$, expression of CD11b, CD14, and CD44 increased similarly for the IT IL- $1 \alpha$ groups. The number of animals per group are 6 controls and 7 in the other groups. ${ }^{*} p<0.05 v s$ control.

controls. Total protein in BALF fluid was $66 \pm 11 \mathrm{mg} / \mathrm{kg}$ for the control lambs and $65 \pm 9 \mathrm{mg} / \mathrm{kg}$ for the $5 \mathrm{mg} / \mathrm{kg} \mathrm{IL}-1 \alpha$ IT group. The total protein in the $50 \mu \mathrm{g} / \mathrm{kg} \mathrm{IL}-1 \alpha$ IT group was 89 $\pm 10 \mathrm{mg} / \mathrm{kg}$, an increase which was not significant. However, three animals were not ventilated for the full $6 \mathrm{~h}$ because of shock and early death.

Cytokine mRNA. Cytokine mRNAs for IL-1 $\beta$, IL-8, IL-6, IL-10 and TNF- $\alpha$ were analyzed using total RNA from a cell pellet from the BALF and from lung tissue (Fig. 3). The 5 $\mu \mathrm{g} / \mathrm{kg}$ and $50 \mu \mathrm{g} / \mathrm{kg}$ IT doses of IL- $1 \alpha$ caused similar 15 to 20 fold increases in IL-1 $\beta$ and IL-8 mRNA and the $50 \mu \mathrm{g} / \mathrm{kg}$ IL- $1 \alpha$ IT increased IL- 10 and TNF- $\alpha$ mRNA almost 10 fold in the cells in the BALF. Both doses of IT IL- $1 \alpha$ caused a nearly 5 fold increase in IL-6 mRNA in the cells of the BALF. The IL-1 $\alpha$ i.v. significantly increased IL-8 in the BALF cells only. Very large increases in IL- 8 mRNA in the lung tissue followed the intratracheal doses of IL- $1 \alpha$. The increases in IL- $1 \beta$, IL-10 and TNF- $\alpha$ mRNA were less striking in lung tissue than in the

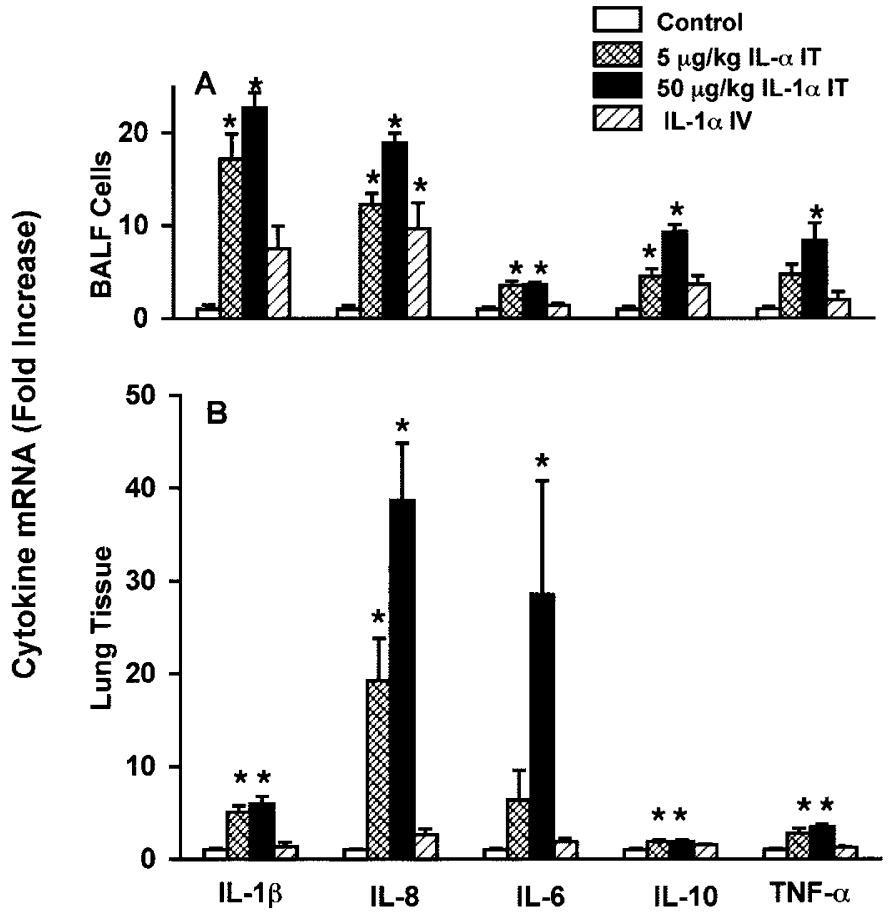

Figure 3. $A$, cytokine mRNA amounts are expressed relative to the mRNA measured for cells from BALF from control animals, which were given a value of 1.0. $B$, cytokine mRNA amounts for lung tissue also were normalized relative to control values. $n=6$ for controls, and 7 for the other groups. ${ }^{*} p<$ 0.05 vs control by ANOVA.

cells from BALF. The IL- 6 mRNA increased in the $50 \mu \mathrm{g} / \mathrm{kg}$ IL- $1 \alpha$ IT lung tissue. The IL- $1 \alpha$ i.v. did not increase any cytokine mRNA in lung tissue.

Surfactant protein mRNA. The IL- $1 \alpha$ exposures did not change the total lung steady state mRNA levels for SP-A or SP-B relative to control lambs (Fig. 4). However, SP-C mRNA levels were decreased by more than $50 \%$ in the animals receiving 5 or $50 \mu \mathrm{g} / \mathrm{kg}$ IL- $1 \alpha$ IT compared with control lambs. SP-D mRNA increased in the $5 \mu \mathrm{g} / \mathrm{kg} \mathrm{IL}-1 \alpha$ IT and 15 $\mu \mathrm{g} / \mathrm{kg} \mathrm{IL}-1 \alpha$ i.v. groups. Total surfactant protein levels were not measured because of the short time course of the study.

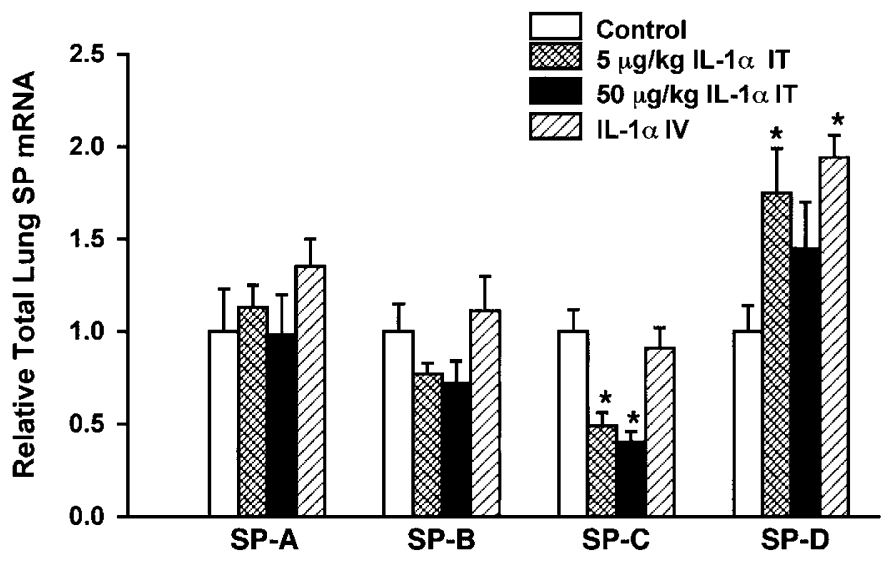

Figure 4. The mRNA for SP-A, -B, -C, and -D were measured and expressed relative to the mean value for the control group. $n=6$ for controls, and 7 for the other groups. $* p<0.05$ vs control. 
Systemic effects of $\boldsymbol{I L}-1 \boldsymbol{\alpha}$. The lambs exposed to IT or i.v. IL- $1 \alpha$ had large decreases in the number of neutrophils in the peripheral blood that occurred by $2 \mathrm{~h}$ and persisted for $6 \mathrm{~h}$ (Fig. 5). Total white blood counts decreased similarly. Blood pressure was lower than in control lambs for the $15 \mu \mathrm{g} / \mathrm{kg}$ IL- $1 \alpha$ i.v. group at $4 \mathrm{~h}$, and two animals in this group died early (Table 1). The heart rate was higher and the blood pressure was qualitatively lower for the $50 \mu \mathrm{g}$ IL- $1 \alpha$ IT group than for the control lambs. Four of the $50 \mu \mathrm{g}$ IL- $1 \alpha$ lambs had either died early or were severely hypotensive at $6 \mathrm{~h}$. The $5 \mu \mathrm{g} / \mathrm{kg} \mathrm{IL}-1 \alpha$ given IT had no systemic effects other than neutropenia.

\section{DISCUSSION}

The proinflammatory cytokines IL- $1 \alpha$ and IL- $1 \beta$ are of particular interest in perinatal medicine because they are early response cytokines that have been associated with multiple adverse outcomes such as preterm delivery, brain injury and cerebral palsy, and bronchopulmonary dysplasia $(4,30,31)$. On the other hand, intraamniotic IL- $1 \alpha$ can induce mRNAs for the surfactant proteins and cause lung maturation in fetal rabbits and sheep $(8,10)$. In vitro IL-1 induces an increase in surfactant protein mRNA in lung explants from early gestation fetuses but decreases the same mRNAs in late-gestation lung explants from rabbits (9). IL-1 induces an inflammatory cascade in animals that is similar to endotoxin. A difficulty in interpreting the effects of an individual cytokine in vivo is the accompanying cascade of mediators that result from a stimulus such as endotoxin. The same problem occurs for interpreting the effects of intraamniotic IL-1 because it induces a chorioamnionitis similar to endotoxin-induced inflammation in sheep $(10,20)$.

We previously reported that $0.1 \mathrm{mg} / \mathrm{kg}$ or $10 \mathrm{mg} / \mathrm{kg}$ IT endotoxin caused severe lung inflammation and a systemic inflammatory response in preterm ventilated lambs (19). The overall responses to $5 \mu \mathrm{g} / \mathrm{kg}$ or $50 \mu \mathrm{g} / \mathrm{kg} \mathrm{IL}-1 \alpha$ given intra-

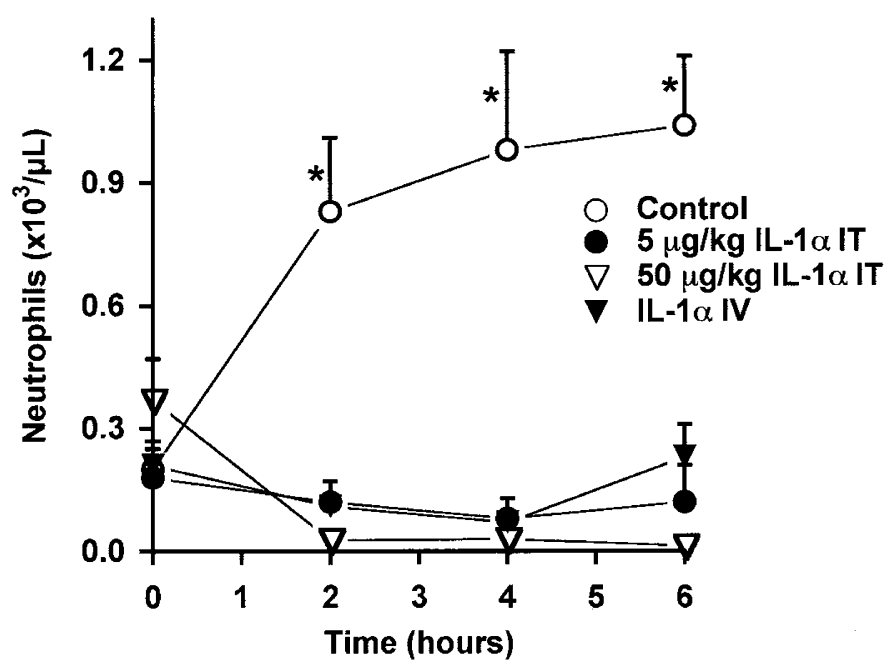

Figure 5. Neutrophils in cord blood were similar for the four groups of lambs. IL-1 $\alpha$ given IT or i.v. resulted in a striking decrease in circulating neutrophils whereas neutrophils increased in the blood of control lambs. Numbers are 6 for control and IT 50 IL- $1 \alpha$ group, 7 for the other groups. ${ }^{*} p<0.05$ s control. tracheally were similar to the endotoxin responses with several exceptions. The lung responses to the lower dose of IL- $1 \alpha$ were essentially equivalent to the higher dose of IL-1 $\alpha$ except that there was decreased gas exchange and a loss of lung gas volume as measured by the pressure-volume curves for the higher-dose group. In comparison to the previous study with endotoxin, neutrophil recruitment to the BALF was qualitatively increased and cytokine mRNA expression was higher with IL-1 $\alpha$, indicating a comparable or exaggerated inflammatory response to IL-1 $\alpha$ in the lungs. However, endotoxin increased $\mathrm{H}_{2} \mathrm{O}_{2}$ production per $10^{6}$ cells, but IL- $1 \alpha$ did not. Because the majority of cells recruited to the BALF were neutrophils with either stimulus, the conclusion is that IL- $1 \alpha$ did not activate neutrophils sufficiently to produce $\mathrm{H}_{2} \mathrm{O}_{2}$. Nevertheless the surface antigens CD11b, CD14, and CD44 were strikingly increased by IL- $1 \alpha$. The IT IL- $1 \alpha$ induced an intense lung inflammation at $6 \mathrm{~h}$ characterized by high levels of proinflammatory cytokine mRNA that included IL-1 $\beta$, IL-6, IL- 8 , and TNF- $\alpha$. The prominent recruitment of neutrophils to the lungs and cytokine expression induced by IL- $1 \alpha$ in the preterm lung is similar to its effects in the adult rat lung with one exception (32). IL- $1 \alpha$ induced a potent oxidant stress mediated primarily by granulocytes in the rat lung, and IL- $1 \alpha$ did not increase $\mathrm{H}_{2} \mathrm{O}_{2}$ in the preterm sheep lung. This lack of response is not explained by a species difference or immaturity, because endotoxin has consistently increased $\mathrm{H}_{2} \mathrm{O}_{2}$ in our fetal and newborn lamb models $(19,33)$.

We recently reported that intraamniotic TNF- $\alpha$ did not cause chorioamnionitis in fetal preterm sheep, and that intravascular TNF- $\alpha$ did not alter fetal blood pressure (20). Intratracheal TNF- $\alpha$ caused a modest inflammatory response in ventilated preterm lambs that was much less striking than the response to IL- $1 \alpha$. The IL- $1 \alpha$ stimulated TNF- $\alpha$ mRNA, but the induced TNF- $\alpha$ should not have contributed to the inflammatory response. This comparison of two early response proinflammatory cytokines in a developing model illustrates the value of testing individual cytokines in developing systems.

An adverse systemic effect of the IT IL- $1 \alpha$ was a fall in blood neutrophils. The decrease in neutrophils occurred rapidly within $2 \mathrm{~h}$, suggesting that the intratracheal dose passed from the lungs into the systemic circulation as we previously documented for endotoxin (19). The rapidity of the response is not consistent with IL-1 inducing secondary mediators. Although we did not attempt to measure IL- $1 \alpha$ in the systemic circulation, the similar decrease in blood neutrophils in response to the i.v. IL- $1 \alpha$ was consistent with the IL- $1 \alpha$ entering the systemic circulation from the lungs despite surfactant treatment and a gentle approach to ventilation of the preterm lung.

A difference between the $50 \mu \mathrm{g} / \mathrm{kg}$ IL- $1 \alpha$ IT and the 15 $\mu \mathrm{g} / \mathrm{kg} \mathrm{IL}-1 \alpha$ i.v. was the more severe hypotension or death in four of seven of the animals given IT IL- $1 \alpha$ versus similar outcomes in only two of seven i.v. IL- $1 \alpha$ animals. Therefore, the high-dose IT IL- $1 \alpha$ must have stimulated a secondary systemic response that was more potent than the i.v. exposure. A possibility is that the i.v. dose resulted in a brief systemic exposure whereas the IT dose likely entered the systemic circulation during a prolonged period, resulting in a more adverse systemic response. Consistent with this possibility was 
the measurement of endotoxin in blood $6 \mathrm{~h}$ after intratracheal injection in preterm lambs (19).

In comparison to an i.v. dose of $5 \mu \mathrm{g} / \mathrm{kg}$ endotoxin in term lambs (19), the i.v. IL- $1 \alpha$ caused less lung inflammation and did not interfere with lung function in preterm sheep. This difference in response could be a dose effect or represent a difference in the lung responses to these agents in the systemic circulation.

The mRNA for SP-C decreased within $6 \mathrm{~h}$ of intratracheal exposure of the ventilated preterm lung to IL- $1 \alpha$. In general, the mRNAs for the surfactant proteins tend to increase after preterm delivery and ventilation (34), and intraamniotic IL- $1 \alpha$ induces lung maturation and large increases in surfactant lipids and the mRNAs for the surfactant proteins in preterm sheep and rabbits $(8,10,20)$. The inhibition of SP-C mRNA is the characteristic response of the term and adult lung to endotoxin, TNF- $\alpha$, or IL- $1 \alpha$ (27). The increased intensity of the inflammatory response after IT IL- $1 \alpha$ may explain the inhibition of SP-C mRNA relative to the inflammatory response to intraamniotic IL-1 $\alpha(20)$.

\section{CONCLUSIONS}

These studies demonstrate that intratracheal IL- $1 \alpha$ is profoundly proinflammatory in the ventilated preterm lung and it can have adverse systemic effects.

\section{REFERENCES}

1. Speer CP 2003 Inflammation and bronchopulmonary dysplasia. Semin Neonatol 8:29-38

2. Van Marter LJ, Dammann O, Allred EN, Leviton A, Pagano M, Moore M, Martin C 2002 Chorioamnionitis, mechanical ventilation, and postnatal sepsis as modulators of chronic lung disease in preterm infants. J Pediatr 140:171-176

3. Leviton A, Paneth N, Reuss ML, Susser M, Allred EN, Dammann O, Kuban K, Van Marter LJ, Pagano M, Hegyi T, Hiatt M, Sanocka U, Shahrivar F, Abiri M, Disalvo D, Doubilet P, Kairam R, Kazam E, Kirpekar M, Rosenfeld D, Schonfeld S, Share J, Collins M, Genest D, Heller D, Shen-Schwarz S 1999 Maternal infection, fetal inflammatory response, and brain damage in very low birth weight infants. Developmental Epidemiology Network Investigators. Pediatr Res 46:566-575

4. Yoon BH, Romero R, Jun JK, Park KH, Park JD, Ghezzi F, Kim BI 1997 Amniotic fluid cytokines (interleukin-6, tumor necrosis factor-alpha, interleukin-1 beta, and interleukin-8) and the risk for the development of bronchopulmonary dysplasia. Am J Obstet Gynecol 177:825-830

5. Tullus K, Noack GW, Burman LG, Nilsson R, Wretlind B, Brauner A 1996 Elevated cytokine levels in tracheobronchial aspirate fluids from ventilator treated neonates with bronchopulmonary dysplasia. Eur J Pediatr 155:112-116

6. Kotecha S, Wilson L, Wangoo A, Silverman M, Shaw RJ 1996 Increase in interleukin (IL) $-1 \beta$ and IL- 6 in bronchoalveolar lavage fluid obtained from infants with chronic lung disease of prematurity. Pediatr Res 40:250-256

7. Fitzgerald KA, O'Neill LA 2000 The role of the interleukin-1/Toll-like receptor superfamily in inflammation and host defence. Microbes Infect 2:933-943

8. Bry K, Lappalainen U, Hallman M 1997 Intraamniotic interleukin-1 accelerates surfactant protein synthesis in fetal rabbits and improves lung stability after premature birth. J Clin Invest 99:2992-2999

9. Glumoff V, Vayrynen O, Kangas T, Hallman M 2000 Degree of lung maturity determines the direction of the interleukin-1-induced effect on the expression of surfactant proteins. Am J Respir Cell Mol Biol 22:280-288
10. Willet K, Kramer BW, Kallapur SG, Ikegami M, Newnham J, Moss T, Sly P, Jobe A 2001 Intra-amniotic injection of IL-1 induces inflammation and maturation in fetal sheep lung. Am J Physiol Lung Cell Mol Physiol 282:L411-L420

11. Dinarello CA, Ikejima T, Warner SJ, Orencole SF, Lonnemann G, Cannon JG, Libby P 1987 Interleukin 1 induces interleukin 1. I. Induction of circulating interleukin 1 in rabbits in vivo and in human mononuclear cells in vitro. J Immunol 139:1902-1910

12. Ikejima T, Okusawa S, Ghezzi P, van der Meer JW, Dinarello CA 1990 Interleukin-1 induces tumor necrosis factor (TNF) in human peripheral blood mononuclear cells in vitro and a circulating TNF-like activity in rabbits. J Infect Dis 162:215-223

13. Shalaby MR, Waage A, Aarden L, Espevik T 1989 Endotoxin, tumor necrosis factor-alpha and interleukin 1 induce interleukin 6 production in vivo. Clin Immunol Immunopathol 53:488-498

14. Dinarello CA 1994 The biological properties of interleukin-1. Eur Cytokine Netw 5:517-531

15. Leff JA, Baer JW, Bodman ME, Kirkman JM, Shanley PF, Patton LM, Beehler CJ, McCord JM, Repine JE 1994 Interleukin-1-induced lung neutrophil accumulation and oxygen metabolite-mediated lung leak in rats. Am J Physiol Lung Cell Mol Physiol 266:L2-L8

16. Patton LM, Saggart BS, Ahmed NK, Leff JA, Repine JE 1995 Interleukin-1 betainduced neutrophil recruitment and acute lung injury in hamsters. Inflammation 19:23-29

17. Wiener-Kronish JP, Albertine KH, Matthay MA 1991 Differential responses of the endothelial and epithelial barriers of the lung in sheep to Escherichia coli endotoxin. J Clin Invest 88:864-875

18. Hybertson BM, Jepson EK, Cho OJ, Clarke JH, Lee YM, Repine JE 1997 TNF mediates lung leak, but not neutrophil accumulation, in lungs of rats given IL-1 intratracheally. Am J Respir Crit Care Med 155:1972-1976

19. Kramer BW, Ikegami M, Jobe A 2002 Intratracheal endotoxin causes systemic inflammation in ventilated preterm lambs. Am J Respir Crit Care Med 165:463-469

20. Ikegami M, Moss TJM, Kallapur SG, Mulrooney N, Kramer BW, Nitsos I, Bachurski C, Newnham JP, Jobe AH 2003 Minimal lung and systemic responses to TNF $\alpha$ in preterm sheep. Am J Physiol Lung Cell Mol Physiol 285:L121-L129

21. Michna J, Jobe AH, Ikegami M 1999 Positive end-expiratory pressure preserves surfactant function in preterm lambs. Am J Respir Crit Care Med 160:634-639

22. Ikegami M, Jobe A 2002 Injury responses to different surfactants in ventilated premature lamb lungs. Pediatr Res 51:689-695

23. Wada K, Jobe AH, Ikegami M 1997 Tidal volume effects on surfactant treatment responses with the initiation of ventilation in preterm lambs. J Appl Physiol 83:10541061

24. Notter RH, Egan EA, Kwong MS, Holm BA, Shapiro DL 1985 Lung surfactant replacement in premature lambs with extracted lipids from bovine lung lavage: effects of dose, dispersion technique, and gestational age. Pediatr Res 19:569-577

25. Lowry OH, Rosebrough NJ, Farr AL, Randall RJ 1951 Protein measurement with the Folin phenol reagent. J Biol Chem 193:265-275

26. Kramer BW, Kramer S, Ikegami M, Jobe A 2002 Injury, inflammation and remodeling in fetal sheep lung after intra-amniotic endotoxin Am J Physiol Lung Cell Mol Physiol 283:L452-L459

27. Bachurski CJ, Pryhuber GS, Glasser SW, Kelly SE, Whitsett JA 1995 Tumor necrosis factor-alpha inhibits surfactant protein C gene transcription. J Biol Chem 270:19402 19407

28. Kallapur SG, Willet KE, Jobe AH, Ikegami M, Bachurski C 2001 Intra-amniotic endotoxin: chorioamnionitis precedes lung maturation in preterm lambs. Am J Physiol Lung Cell Mol Physiol 280:L527-L536

29. Bachurski CJ, Ross GF, Ikegami M, Kramer BW, Jobe AH 2001 Intra-amniotic endotoxin increases pulmonary surfactant components and induces SP-B processing in fetal sheep. Am J Physiol Lung Cell Mol Physiol 280:L279-L285

30. Grether JK, Nelson KB, Dambrosia JM, Phillips TM 1999 Interferons and cerebral palsy. J Pediatr 134:324-332

31. Goldenberg RL, Hauth JC, Andrews WW 2000 Intrauterine infection and preterm delivery. N Engl J Med 342:1500-1507

32. Hybertson BM, Lee YM, Cho HG, Cho OJ, Repine JE 2000 Alveolar type II cell abnormalities and peroxide formation in lungs of rats given IL-1 intratracheally. Inflammation 24:289-303

33. Kramer BW, Moss TJ, Willet K, Newnham J, Sly P, Kallapur SG, Ikegami M, Jobe A 2001 Dose and time response after intra-amniotic endotoxin in preterm lambs. Am J Respir Crit Care Med 164:982-988

34. Woods E, Ohashi T, Polk D, Ikegami M, Ueda T, Jobe AH 1995 Surfactant treatment and ventilation effects on surfactant SP-A, SP-B, and SP-C mRNA levels in preterm lamb lungs. Am J Physiol Lung Cell Mol Physiol 13:L209-L214 